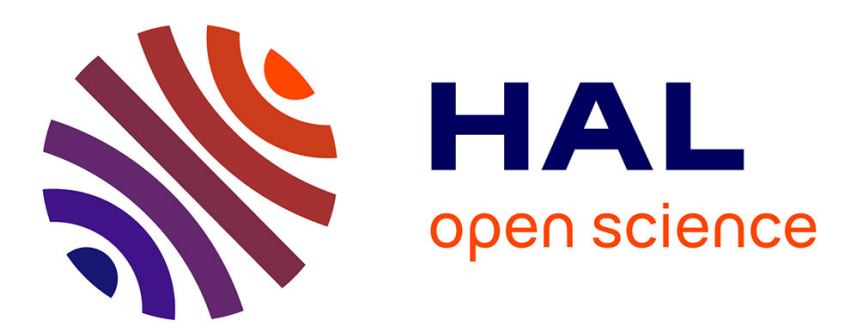

\title{
Diverse impacts of the determinants of entrepreneurial intention: three submodels, three student profiles
} Jean-Pierre Boissin, Véronique Favre-Bonté, Sandrine Fine Falcy

\section{To cite this version:}

Jean-Pierre Boissin, Véronique Favre-Bonté, Sandrine Fine Falcy. Diverse impacts of the determinants of entrepreneurial intention: three submodels, three student profiles. Revue de l'Entrepreneuriat, 2017, 16 (3-4), pp.17-43. 10.3917/entre.163.0017 . hal-01700675

\section{HAL Id: hal-01700675 \\ https://hal.univ-smb.fr/hal-01700675}

Submitted on 5 Feb 2018

HAL is a multi-disciplinary open access archive for the deposit and dissemination of scientific research documents, whether they are published or not. The documents may come from teaching and research institutions in France or abroad, or from public or private research centers.
L'archive ouverte pluridisciplinaire HAL, est destinée au dépôt et à la diffusion de documents scientifiques de niveau recherche, publiés ou non, émanant des établissements d'enseignement et de recherche français ou étrangers, des laboratoires publics ou privés. 


\title{
BOISSIN J-P., Université Pierte Mendès France, CERAG FAVRE-BONTE V., Université Savoie Mont Blanc, IREGE FINE-FALCY S., Université Grenoble Alpes, CERAG
}

\section{DIVERSE IMPACTS OF THE DETERMINANTS OF ENTREPRENEURIAL INTENTION}

\begin{abstract}
Nations seek greater diffusion of entrepreneurial culture among students, yet discussions about the appropriate educational approaches continue to be marked by divergent opinions. To provide a better understanding of entrepreneurial intention formation among students, research is critical. This article, in keeping with this goal, investigates the entrepreneurial capacities and attitudes of students toward entrepreneurship, by identifying subgroups within a student population that is often regarded as homogeneous. Although literature on entrepreneurial intentions is abundant, more recent research calls for more empirical investigations that can outline the differences in entrepreneurial intentions among subgroups of student populations.
\end{abstract}

Keywords: Entrepreneurial intention; capacity to start a business; student; entrepreneurship. 


\section{INTRODUCTION}

The global consensus regarding the central role of entrepreneurship in the development of economies suggests the need for higher education to ensure the dynamic promotion of and support for entrepreneurship among the youth. In the "Enterprise Plan of Action 2020-Reviving the Enterprise Spirit in Europe," the European Commission recommends that every student who so chooses should be trained to start a business program on his or her campus. For example, various measures were put in place in September 2014 in France, such as the creation of a studententrepreneur status. The sustainability of these measures in turn requires assessments of their impact. France's national government anticipates broader diffusion of the entrepreneurial culture among students, as well as more graduates transitioning to entrepreneurial careers. Beyond gauging the number of affected students, assessments should recommend adjustments to pedagogy and early support for entrepreneurship, according to the profiles of the students. However, the discussion about the choice of pedagogic approaches has not kept pace. Opinions on this subject diverge (Byabashaija and Katono, 2011; Fayolle and Gailly, 2009), and most programs continue to rely on an action-based pedagogy. To help pertinent actors recognize the methodological choices available and guarantee the efficiency of the lessons and early support, research can help, by clarifying the processes by which entrepreneurial intentions are formed. In turn, research can inform universities about how to reach their target markets of students. Higher education students have not necessarily made their ultimate professional choices; instead, they are in the process of developing intentions, according to existing frameworks of how people develop their professional orientation (Ozaralli and Rivenburgh, 2016).

This article therefore investigates the entrepreneurial capacities and attitudes of students by identifying subgroups within the student population, which often is assumed to be homogeneous. Literature on entrepreneurial intentions is abundant (Linan and Fayolle, 2015) and indicates that intentions are strong predictors of behavior (Armitage and Conner, 2001), even if they are not sufficient to drive that behavior (Krueger, 1993; Bruyat, 2001; Chabaud and Messeghem, 2010). However, recent literature (Schlaegel and Koenig, 2014) has called for more empirical studies to provide additional explanatory power and a fuller understanding of the process through which entrepreneurial intentions develop, including differences in the processes of developing intentions, according to membership in subgroups of the population (Rueda et al., 2015). In turn, the current research considers a pertinent research question: Is intention model relevant to all students? In other words, do different intention formation submodels exist according to different students' profiles?

By focusing on students' entrepreneurial intentions, this study seeks to shed light on elements that have remained insufficiently explored in prior literature, including the variables that mark the start of an entrepreneurial intention, diversity in profiles, and entrepreneurial intentions in the short and long term. Describing the process by which students form entrepreneurial intentions might help improve the offers of educational programs devoted to entrepreneurship (Bae et al., 2014). Specifically, these programs should balance the needs of different student profiles to ensure their ability to catalyze the entrepreneurial spirit of a vast range of students.

Furthermore, the variety of definitions of entrepreneurial intentions reveals a lack of consensus about the term's significance (e.g., Shook et al. 2003; Moreau and Raveleau, 2006). We adopt Kolvereid's (1996) approach, which includes what Ajzen and Fishbein (1980) call a choice intention. Intention refers to the choice between following an entrepreneurial career versus a salaried career. To understand entrepreneurial intention, we rely on psychosocial models of intention, such as Ajzen's (1991) theory of planned behavior (TPB). Prior investigations of such concepts by various authors confirm their usefulness for our study context (Schlaegel and Koenig, 2014).

In turn, our research has three main objectives: (1) to propose an extension to the theory of planned behavior, reflecting the specificities of student populations; (2) to specify how the weights 
of the determinants of entrepreneurial intention differ according to student profiles; and (3) to characterize students' profiles according to available socio-demographic variables.

In the next section, we present models of entrepreneurial intention to derive our working hypotheses. We then describe the methodology we used to test a general model of entrepreneurial intention and its submodels. In turn, we discuss the need for specifying, according to student profiles, the models by which students form an awareness of entrepreneurship.

\section{INTENTION MODELS, BY STAGE IN STUDENTS’ CAREER CHOICE PROCESS}

This section presents different intention models that can apply to entrepreneurial behavior, reflecting the specificities of the varied entrepreneurial intentions that appear across student populations. In turn, we address the relevance of the TPB model; despite this relevance, we also note the lack of consensus regarding the relative importance of the different determinants of entrepreneurial intention across diverse student populations.

\subsection{The relevance of the theory of planned behavior for studying entrepreneurial intentions among students}

Many researchers apply intention models to explain the act of business creation (Krueger, 1993; Krueger et al., 2000), mostly inspired by Ajzen's (1991) TPB (Appendix 1) or entrepreneurial event models (EEM, Shapero and Sokol, 1982). Intention is a strong predictor of behavior (Armitage and Conner, 2001). In a meta-analysis of 98 studies of the process of entrepreneurial intention (EI) formation, conducted over the past 25 years in more than 30 countries, Schlaegel and Koenig (2014, p. 318) show that an integrated model (TPB-EEM) accounts for .31 of the variance in EI compared with .28 for the TPB and .21 for the EEM. Moreover, the perceived behavioral control-EI relationship (TPB) is better than the perceived desirability-E $I^{1}$ relationship (EEM), and the effect size is stronger for student samples compared with nonstudent samples.

Therefore, we adopt the TPB model and measures from Kolvereid (1996) to ensure continuity, enrich the model, and provide research replications (Schlaegel and Koenig, 2014). According to this approach, three elements influence intention (Ajzen, 1991):

- Perceived control, or individual perceptions regarding a person's own ability to accomplish a particular behavior. This concept is similar to self-efficacy as defined by Bandura (1997) (Krueger et al., 2000; Kolvereid and Isaksen, 2012).

- Attitudes, defined as an individual global evaluation of behavior.

- Subjective norms, or individual perceptions of social pressures to engage (or not) in entrepreneurial behavior (Ajzen, 1991). This element has two parts: normative beliefs and motivation to conform to these beliefs.

These three elements of intention were also validated on a student population (Kolvereid, 1996; Krueger et al., 2000). So, as the first step of this research, we therefore tested the following predictions, derived from the general TPB model:

H1: Perceived control has an influence on intention.

H2: Attitudes have an influence on intention.

H3: Subjective norms have an influence on intention.

Nevertheless, the results of previous studies diverge somewhat (Rueda et al., 2015), so we also consider possible enrichments to this model to solidify the results as they relate to business students.

\footnotetext{
${ }^{1}$ Perceived desirability is one of three variables in this model, along with propensity to act and perceived feasibility.
} 
Intention models, including the TPB, imply some determinism of variables that generally are presumed to be independent, such as attitude, subjective norms, and perceived control (Kolvereid, 1996). Attitude is widely assumed to dominate models of entrepreneurial intention among students (Audet, 2000; Boissin et al., 2009; Ozaralli and Rivenburgh, 2016). As students are still building their skills, they tend to rely on their attitude rather than their perceived control to build their professional orientation. However, the variables also interact; attitude can be influenced by subjective norms and perceived control (Ajzen, 1991). Several researchers argue for reconceptualizing subjective norms, which often fail to predict intention (Krueger, Reilly, and Carsrud, 2000). Liñán and Chen (2009) argue that subjective norms represent an initial mental filter of the external stimuli that influence the process of intention formation, such that their main influence moves through attitudes. Fretschner and Weber (2013) concur that the effect of subjective norms on entrepreneurial intentions is mediated by personal attitude. In the same way we can question the link between perceived control and attitude, of which Schlaegel and Koenig (2014) often show a strong correlation. Perceived control thus seems to reinforce the attitude. Therefore, we hypothesize:

H4: Attitude is the dominant variable affecting entrepreneurial intentions.

H5: Attitude mediates the effects of (a) subjective norms and (b) perceived control.

Even if the TPB offers the best account of entrepreneurial intentions among young people, an issue persists, namely, predicting behavior in the long term. This difficulty, first noted by Ajzen and Fishbein (1980), was reaffirmed by Audet (2000). Perceived desirability and feasibility can explain $53 \%$ of the variation in EI in the long term, relative to $26 \%$ in the short term. Therefore, it seems important to consider temporal differences, such that we separate short-term intentions (i.e., immediately after students graduate) and long-term intentions in our model, and we predict:

H6. The influence of determinants of entrepreneurial intention varies, depending on whether the intentions are measured in the short or long term.

\subsection{Diversity of the student population}

To compensate for some limitations in previous research (Rueda et al., 2015; Ozaralli and Rivenburgh, 2016), we highlight some elements that might enable us to refine the global model. No clear evidence exists regarding the divergent results obtained in prior studies. Depending on the study, the importance of each variable in the model differs. Schlaegel and Koenig (2014) and Kolvereid (1996) show that subjective norms have strong predicative power, but Krueger et al. (2000) conclude that only perceived feasibility ${ }^{2}$ and attitude toward the behavior influence intentions, excluding subjective norms. Some studies identify interactions among the variables; the potential influences of these interactions on the antecedents of intention demand investigation (Fitzsimmons and Douglas, 2011). We thus integrate extant results, and notably the synthesis offered by Schlaegel and Koenig (2014), which depicts the connections among the variables.

In addition, many studies consider entrepreneurial intentions among student populations (Kolvereid, 1996; Tkachev and Kolvereid, 1999; Carrier, 2000; Fayolle, 2001; Luthje and Franke, 2003; Plant and Ren, 2010). However, research that addresses the impacts of various courses of study are rare (Boissin et al., 2009). Rather, most analyses concentrate on students in a particular field, such as engineering, commerce, technology, or even medicine. Thus prior studies appear focused exclusively on observations of entrepreneurial intentions among certain student profiles, to the exclusion of others. In France, the Program Students for Innovation, Transfer, and Entrepreneurship (PEPITE) covers such intentions, as well as awareness of the need for advanced support of entrepreneurial projects according to distinct phases, reflecting the different maturity levels of the

\footnotetext{
${ }^{2}$ Perceived feasibility, for Krueger et al. (2000), combines entrepreneurial self-efficacy and perceived behavioral control.
} 
students. Some studies also offer classifications within the populations being studied, suggesting differences of representation (Schlaegel and Koenig, 2014). Therefore, we can establish a stable, unique hierarchy of antecedents of intention, in a general model framework, while still endeavoring to propose representations of submodels of intention, according to each subgroup in the typology.

The goal is not to understand if the TPB is appropriate for representing the process of entrepreneurial intention formation; rather, this research seeks to understand differences in the values of its elements, according to the groups to which an individual student belongs (Rueda et al., 2015). In other words, the submodels of entrepreneurial intention, specific to each subgroup, constitute opportunities to respond better to the needs of students in entrepreneurial education programs, by delineating the processes by which differentiated intentions form.

To move beyond the validation of a global model of entrepreneurial intention, we thus tested for the presence of submodels that could reflect subgroups of students and the interaction of the key variables, according to the following hypothesis:

H7: Specific submodels exist to describe the formation of entrepreneurial intentions by subgroups of students.

Figure 1 presents the model and details our hypotheses.

Figure 1. Model of hypotheses tests

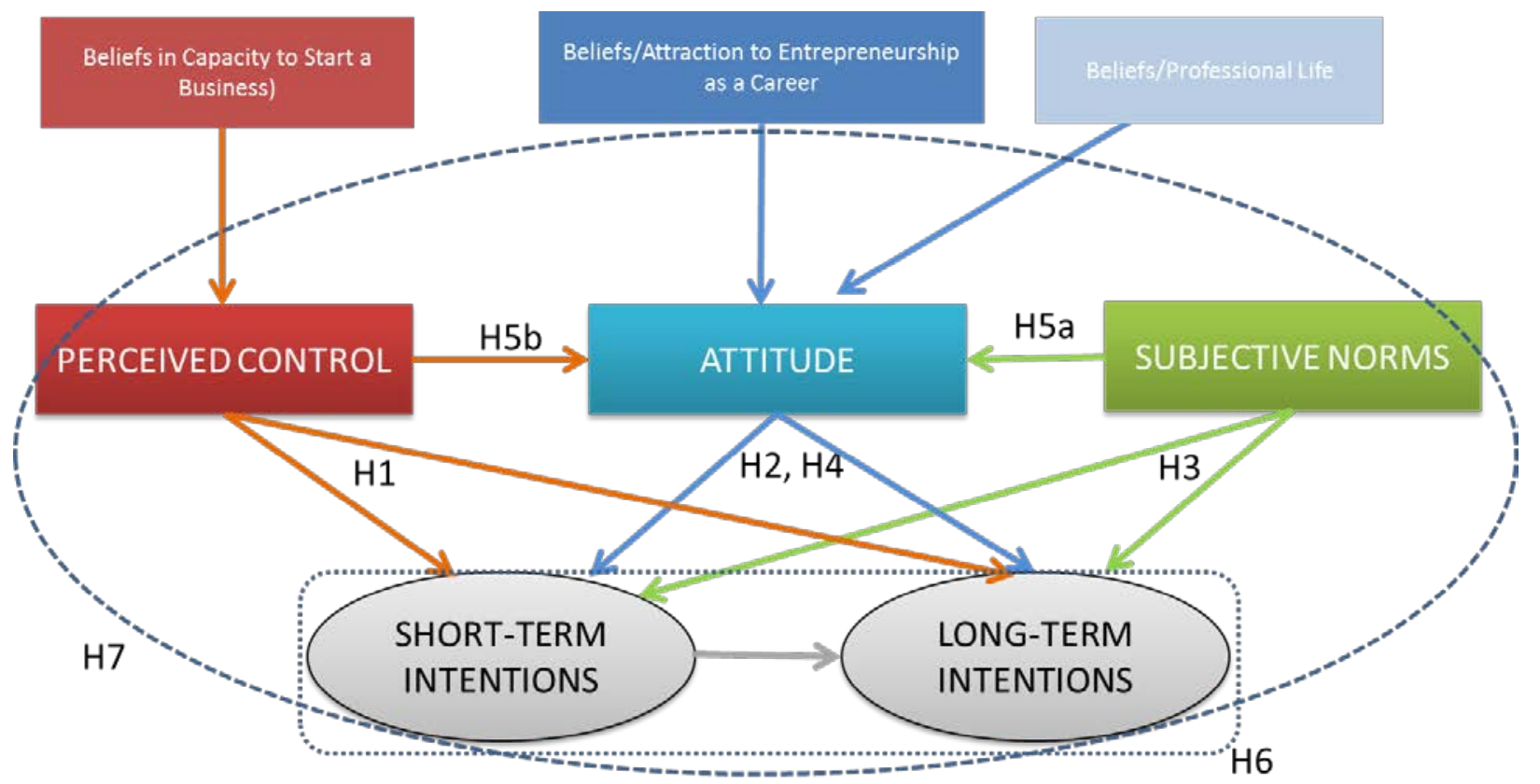

\section{SAMPLE AND METHODOLOGY}

This article aims to characterize the diversity of students, related to their entrepreneurial intentions, in an effort to support educational designs that can support their projects and 
entrepreneurial behaviors. Accordingly, we conducted a quantitative study of entrepreneurial representations among student populations in several higher education establishments in the MidiPyrenees region (Toulouse) of France (Appendix 2).

Studies that describe which courses of study lead to intentions are rare (Boissin et al., 2009). Therefore, we chose to survey students from diverse fields. Using the Survey Monkey platform, we sent surveys to 100,000 students from the Midi-Pyrenees region (Toulouse), through an intermediary at each university in the area. Although we received 4,614 questionnaires, some were missing responses. After excluding incomplete questionnaires, our sample consisted of 2,267 student respondents, representing various courses of study. Table 1 presents the main sample characteristics.

Table 1. Sample Description

\begin{tabular}{|c|c|}
\hline Descriptive variables & Percentage of the sample \\
\hline \multicolumn{2}{|l|}{ Study domains } \\
\hline Law, economics, or social sciences & 8.3 \\
\hline Administration, management, business & 18.5 \\
\hline Arts, letters, languages, and humanities & 5.8 \\
\hline Life sciences and health sciences & 7.5 \\
\hline Sciences, engineering, technology & 46.8 \\
\hline Other & 13.2 \\
\hline \multicolumn{2}{|l|}{ Level of studies } \\
\hline Bachelor level (bac. +1 to bac. +3 ) & 51.5 \\
\hline Master’s level (bac. +4 to bac. +5 ) & 35.8 \\
\hline Doctorate level & 12.7 \\
\hline \multicolumn{2}{|l|}{ Gender } \\
\hline Male & 47.7 \\
\hline Female & 52.3 \\
\hline \multicolumn{2}{|l|}{ Age Ranges } \\
\hline Under 21 years & 58.8 \\
\hline 21 to 23 years & 40.5 \\
\hline 24 years of age and older & 0.7 \\
\hline \multicolumn{2}{|l|}{ National Origin } \\
\hline France & 91 \\
\hline Western Europe & 2.2 \\
\hline Eastern Europe & 0.8 \\
\hline Africa & 3.4 \\
\hline Oceania & 1.9 \\
\hline South America & 0.7 \\
\hline North America & 0.2 \\
\hline \multicolumn{2}{|l|}{ Parents as Entrepreneurs? } \\
\hline Yes & 30.2 \\
\hline No & 69.8 \\
\hline \multicolumn{2}{|l|}{ Proximity to Entrepreneurs? } \\
\hline Yes & 54.2 \\
\hline No & 45.8 \\
\hline
\end{tabular}

\section{Questionnaire}

The questionnaire items in the first part mainly come from prior studies that seek to measure the variables in Ajzen's (1991) model (i.e., start-up capacities, beliefs about the enterprise, beliefs about professional life, perceived control, attitudes, and subjective norms; Kolvereid, 1996). The 
items to measure subjective norms, before being analyzed, were assessed according to their importance to each individual. Another section of the questionnaire contains items about the outcome variables (e.g., short- vs. long-term intentions), to address the limits associated with the model. Entrepreneurial intention thus is evaluated with three items recommended by Kolvereid (1996), pertaining to the intention to get started immediately after school or at a later time. The measures use five-point Likert-type scales. Appendix 3 shows the collection of items organized by concept in the questionnaire. ${ }^{3}$ We also measured descriptive variables, to be able to characterize the respondents and evaluate where and when they might have developed entrepreneurial intentions.

\section{Operationalization of the variables}

The items explaining beliefs, perceived control, attitude, and subjective norms were subjected to exploratory factorial analyses in SPSS, then confirmed by a partial least squares analysis, to specify the dimensions underlying each concept. Second-order analyses were applied to some constructs (beliefs/capacity, beliefs/attraction for entrepreneurship, and beliefs/professional life). The results, in Appendix 3, confirm the quality of the measures used in the model, in terms of both their reliability and their convergent validity (Henseler et al., 2009).

\section{Analyses}

The analysis of the information involved three stages, reflecting the specific objectives that defined the statistical analyses applied (see Table 2):

1. The main stage tests the general model of the formation of entrepreneurial intentions, using structural equations in XLSTAT. To represent the tested model according to the student population in the Midi-Pyrenees region (France), we readdressed the sample, accounting for the relative importance of different schools. With this method, we confirm the quality of the model and estimate the strength of the connections among the model concepts.

2. To identify homogeneous groups of students that form their entrepreneurial intentions in specific ways, we used a latent class approach, called one-step mixture confirmatory analysis, or REBUS-PLS (Esposito Vinzi et al., 2008). This method detects sources of heterogeneity in both structural and measurement models for all latent variables and offers more efficiency than traditional typological methods (Farooq et al., 2013). Then, with tests of permutation (Chin and Dibbern, 2010), we seek to confirm the stability of the model among the different groups, according to the invariance of the measures used to compare the strength of the relations among the constructs.

3. We characterize the profiles of the majority of the students for each type of process, with the assistance of chi-square tests or F-tests of the principal and descriptive variables.

\footnotetext{
3 The length of the questionnaire prevents us from including it here; it is available on request.
} 
Table 2. Three information analysis stages

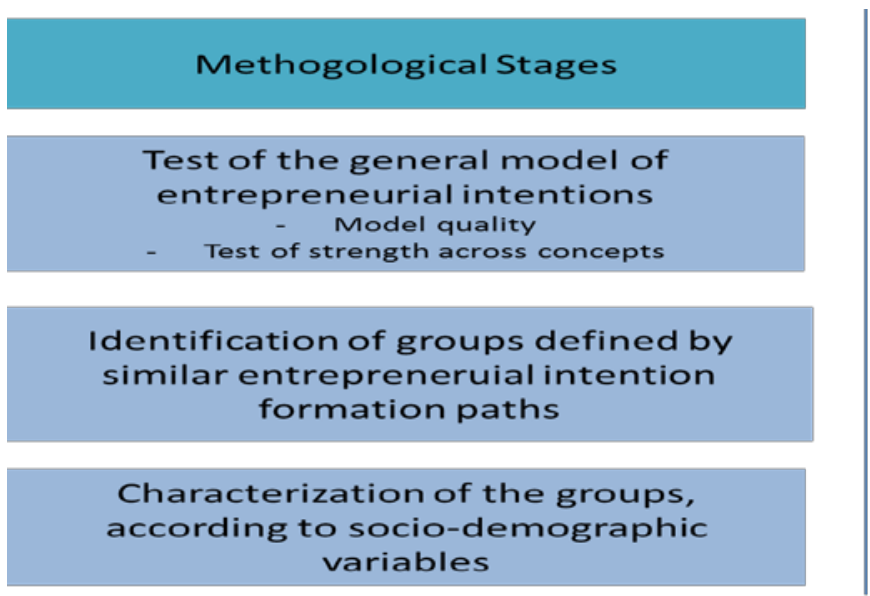

Structural Equation Modeling with Partial Least Squares (PLS)

One Step Mixture Confirmatory Analysis, Rebus-PLS

Chi-square or F-tests

\section{MAIN RESUlts}

The results reveal how students regard entrepreneurship, in terms of their perceptions and their intentions toward entrepreneurship in general, even though the questionnaire leaned more toward business creation than toward general entrepreneurship issues. We present the results in two parts: the general model of entrepreneurial intentions, and then separate analyses of each of three student groups (revealed by a latent classification) that differ in the processes by which they develop their entrepreneurial intentions.

\subsection{General model of entrepreneurial intention formation: global results}

The initial test of the global validity of the model reveals satisfactory indicators (relative goodness of fit $[\mathrm{GoF}]=.832$, absolute $\mathrm{GoF}=0.537$ ), so we can interpret the results (see figure 2). ${ }^{4}$ Before starting this analysis, we note that few students express intentions to create their own business at the end of their studies (averages: 1.86 in short-term; 3.32 in the long-term; see Appendix 4).

\footnotetext{
${ }^{4}$ The results of the tests of the measure and the descriptive analysis of the variables are available in Appendices 3 and 4 , respectively.
} 


\section{Figure 2. General model of entrepreneurial intention formation}

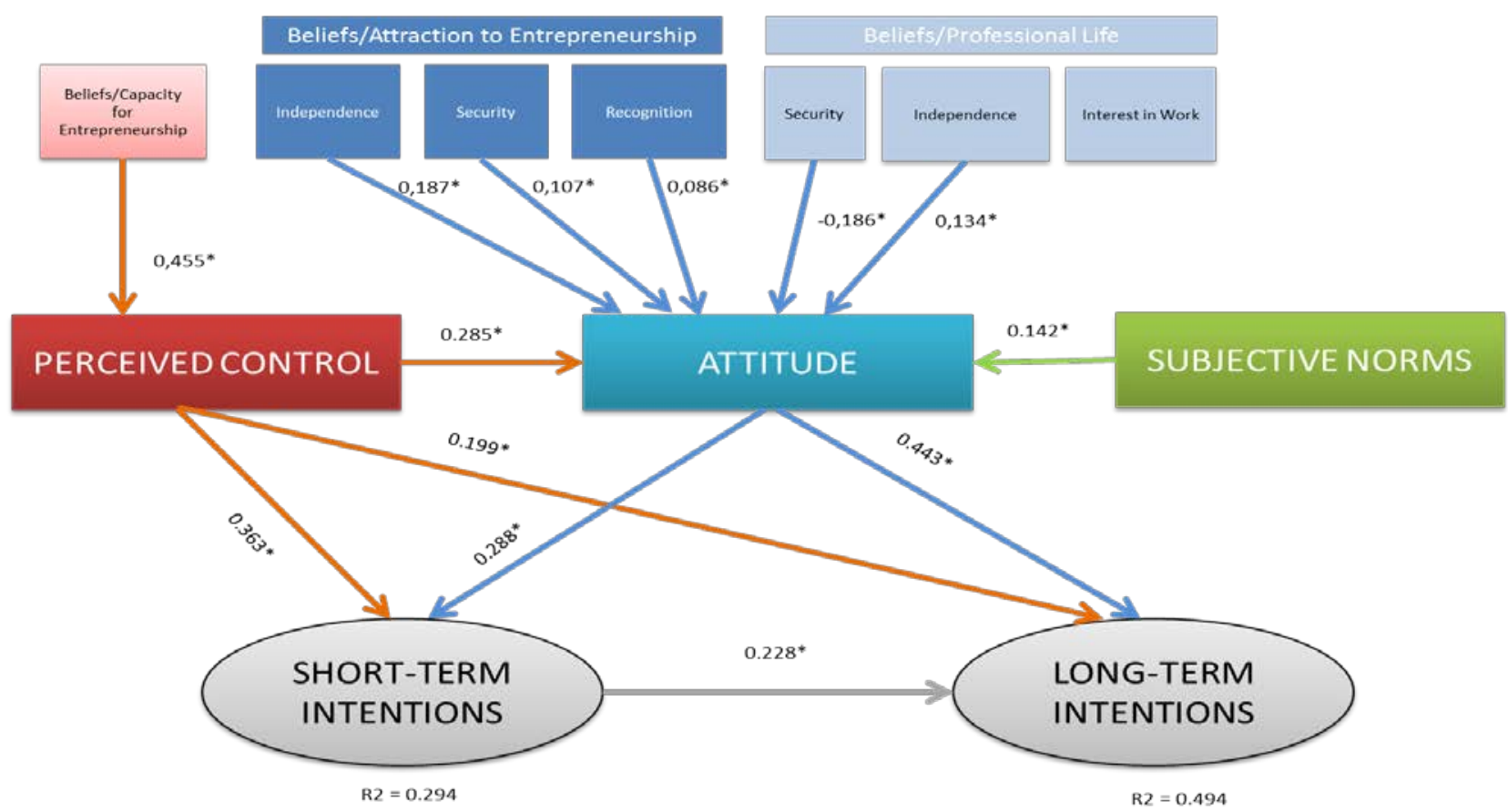

*Path coefficient significant at $1 \%$.

**Path coefficient significant at 5\%.

This evidence provides partial validation of our hypotheses. Both H1 (influence of perceived control on intentions) and $\mathrm{H} 2$ (influence of attitudes on intentions) receive support. However, subjective norms have no direct impact on intentions, in contrast with $\mathrm{H} 3$, and regardless of the temporal dimension. Attitude is the principal influence on the formation of intentions (H4) in the long term (.443 vs. .199 for perceived control); in the short term though, the situation reverses, such that perceived control has a more important role (.363 vs. .288 for attitude). Thus perceived control has a stronger impact on the intentions of students to create their own enterprise at the end of their studies. This short- versus long-term view influences intention formation (H6).

Subjective norms work on attitudes (H5a), which then influence intentions in the short and long terms. Furthermore, subjective norms exercise an indirect influence on intention to begin acting on attitudes. With this result, we can explain some of the controversies in prior literature (Schlaegel and Koenig, 2014). Yet attitude is also influenced by perceived control (H5b) and mediates the formation of entrepreneurial intention. For this confirmation of a general model of entrepreneurial intention, we relied on a one-step mixture confirmatory analysis. In so doing, we also identified three profiles of students, according to the ways they form their entrepreneurial intentions.

\subsection{Three sub-models of entrepreneurial intention formation}

The REBUS-PLS analysis suggests an optimal solution that consists of three groups, defined by the formation models they adopt toward the development of their entrepreneurial intentions (in support of H7). 
Submodel G1. The first submodel (G1) reflects the fewest students, with only 210 members from our sample (see Figure 3).

\section{Figure 3. Internal submodel of entrepreneurial intention formation, Group $1^{5}$}

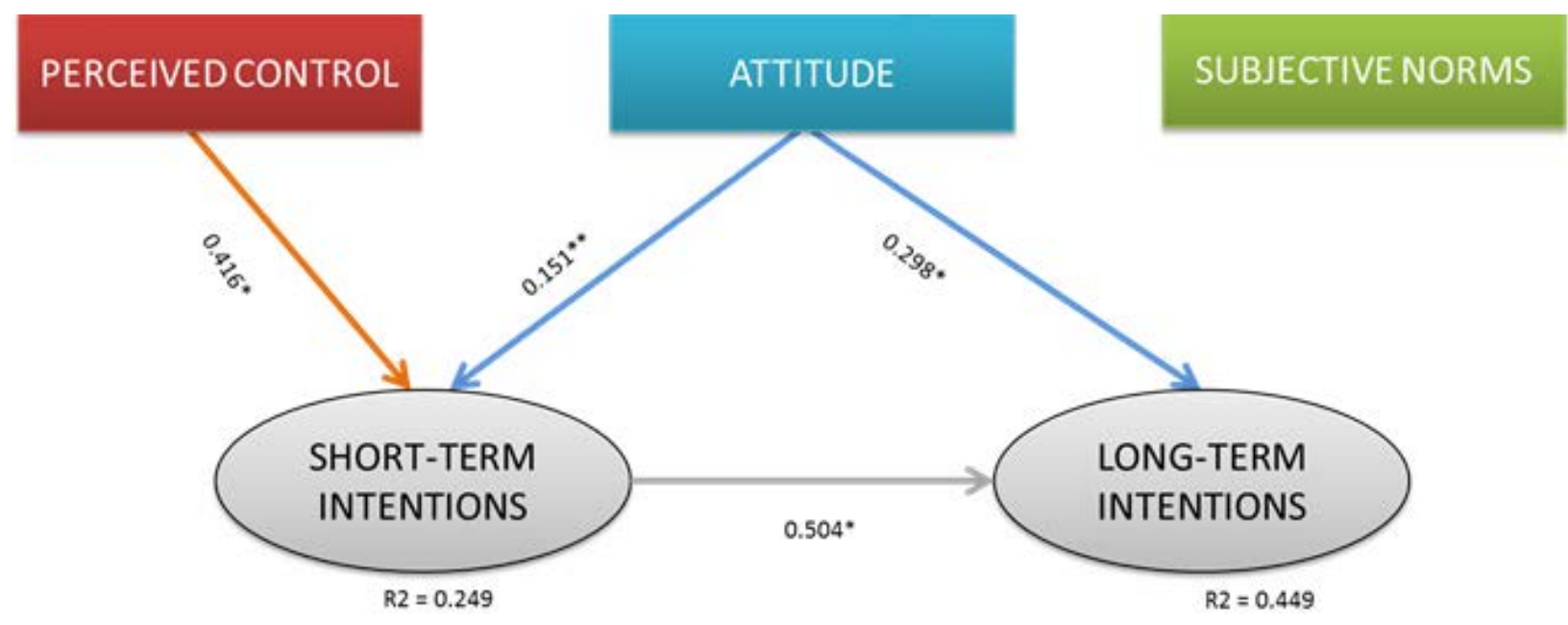

*Path coefficient significant at $1 \%$.

**Path coefficient significant at 5\%.

Similar to the general model, this submodel confirms $\mathrm{H} 1$ and $\mathrm{H} 2$ regarding the influences of perceived control and attitude on intentions. We also again must reject $\mathrm{H} 3$, because subjective norms exercise no influence.

However, contrary to the general model of entrepreneurial intention, attitude is not influenced by subjective norms and perceived control (H5). In effect, neither perceived control or subjective norms influence attitude. Furthermore, perceived control no longer exhibits an impact on intentions in the long term. Thus we find the same predominance of the influence of perceived control as in the general model: Its influence on intention at the end of studies is markedly more important (.416) than that of attitude (.151). These results prevent us from confirming $\mathrm{H} 4$ with regard to the dominant influence of attitude.

The students in this group do not hope to create a business right after they finish their studies (or in the long term), for two main reasons. First, they regard the idea of creating their own enterprise as only slightly attractive. Second, they do not see themselves as any more than somewhat capable of initiating a business in the short and long terms (see Appendix 4). Regarding this weak desire to undertake entrepreneurship and their equally weak attitudes and perceived control, these students can be qualified as "recalcitrants." Their intention formation also is based on different factors in the short versus long term (H6), such that their short-term intentions primarily stem from their weak perceived control. The slightly more favorable long-term intentions, which are better explained by the model than their short-term intentions, instead depend on their intentions in the short term and on their attitudes.

\footnotetext{
${ }^{5}$ Our research objective pertains to identifying the differential impacts of the three principal determinants, so we opted for a simplified representation of the model, revolving around the relations among perceived control, attitudes, subjective norms, and short- and long-term intentions.
} 
This group is composed principally of women, studying law, economics, humanities, arts, letters, or life and health sciences. It consists of members who pursue a course of study that is not traditional and contrary from programs devoted to entrepreneurial education. Across these varied origins, their level of education is generally Baccalaureate +1 or doctorate. Furthermore, G1 members appear to believe that entrepreneurs and business founders in their group are largely failures.

Submodel G2. The second submodel includes more people, with a total of 1,318 students (Figure 4).

Figure 4. Internal submodel of entrepreneurial intention formation, Group 2

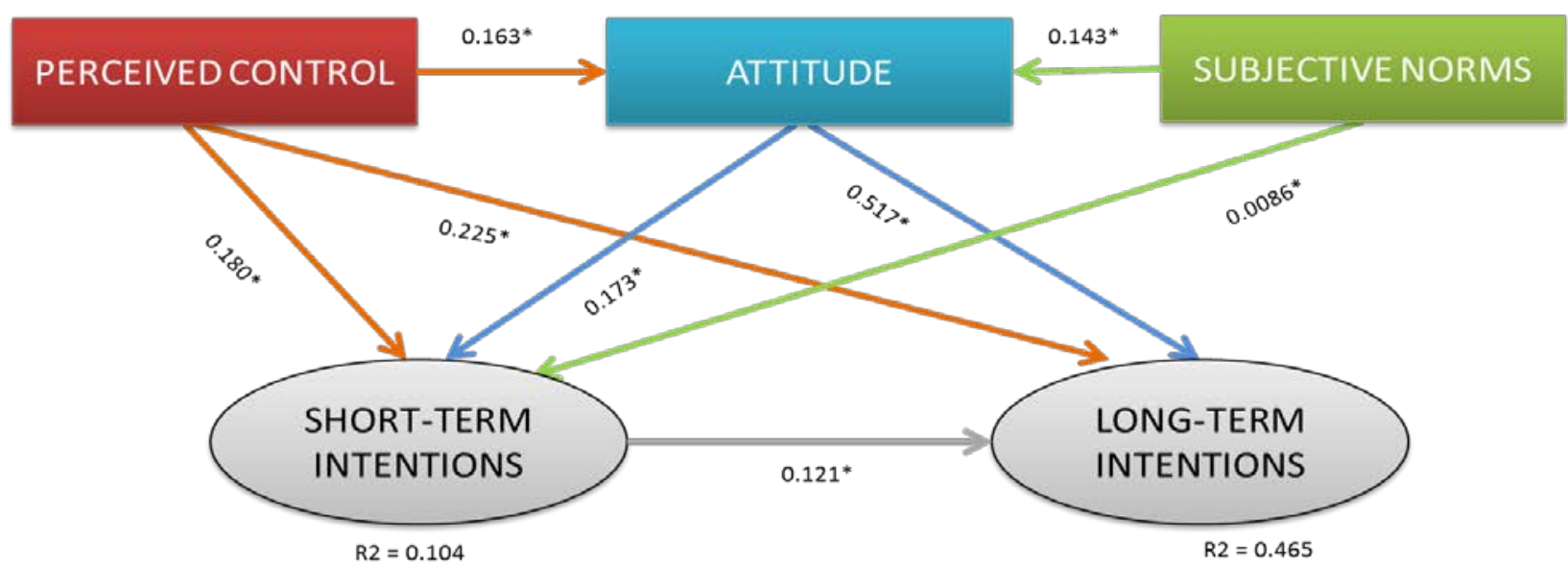

*Path coefficient significant at $1 \%$.

**Path coefficient significant at 5\%.

The separate modeling of subgroup G2 (H7) helps validate $\mathrm{H} 1$ and $\mathrm{H} 2$ regarding the influences of perceived control and attitudes on intentions in the short and long terms. Subjective norms have a weak but significant influence on intentions in the short term. In line with the general model, subjective norms have a small effect on attitude (H5a), as does perceived control (H5b). Thus attitude again functions as a mediating variable.

Students in this group indicate that their short-term entrepreneurial intentions, at the end of their studies, depend almost equally on perceived control and attitude. In the long term though, the influence of attitude (H4) dominates (.517) over perceived control (.225). Accordingly, the variables do not have the same influence over time (H6). Furthermore, these students show the weakest shortterm intentions in the sample, and the resulting submodel is the least well explained $\left(r^{2}=.104\right)$. All the determinants play a role, but a modest one. Then in the long term, their intentions are clearer $\left(\mathrm{r}^{2}\right.$ $=.465$ ), with a very strong attitude weight that catalyzes the effects of both perceived control and subjective norms.

This group shows the weakest intention to create an enterprise in the short term. In the long term though, this intention increases a little. These students have a more positive attitude toward the act of starting a business; the idea of creating a business seems attractive (more so than for G1), but they do not regard themselves as capable of creating an enterprise in the short term (Appendix 4). They thus can be designated "ambivalents," because of their weak short-term intentions, which increase in the long term, due to the strong determinant of a favorable attitude.

The members of subgroup G2 are women and French natives, with an average educational level of Baccalaureate +5 . They mostly study law, economics, human and social sciences, 
engineering, or technology. They know few people who have created enterprises, and most of those persons failed. Although these students have not particularly followed a program of entrepreneurial education, they believe that entrepreneurship could turn out to be both useful and interesting.

Submodel G3. The third submodel reflects 739 individuals (Figure 5).

\section{Figure 5. Internal submodel of entrepreneurial intention formation, Group 3}

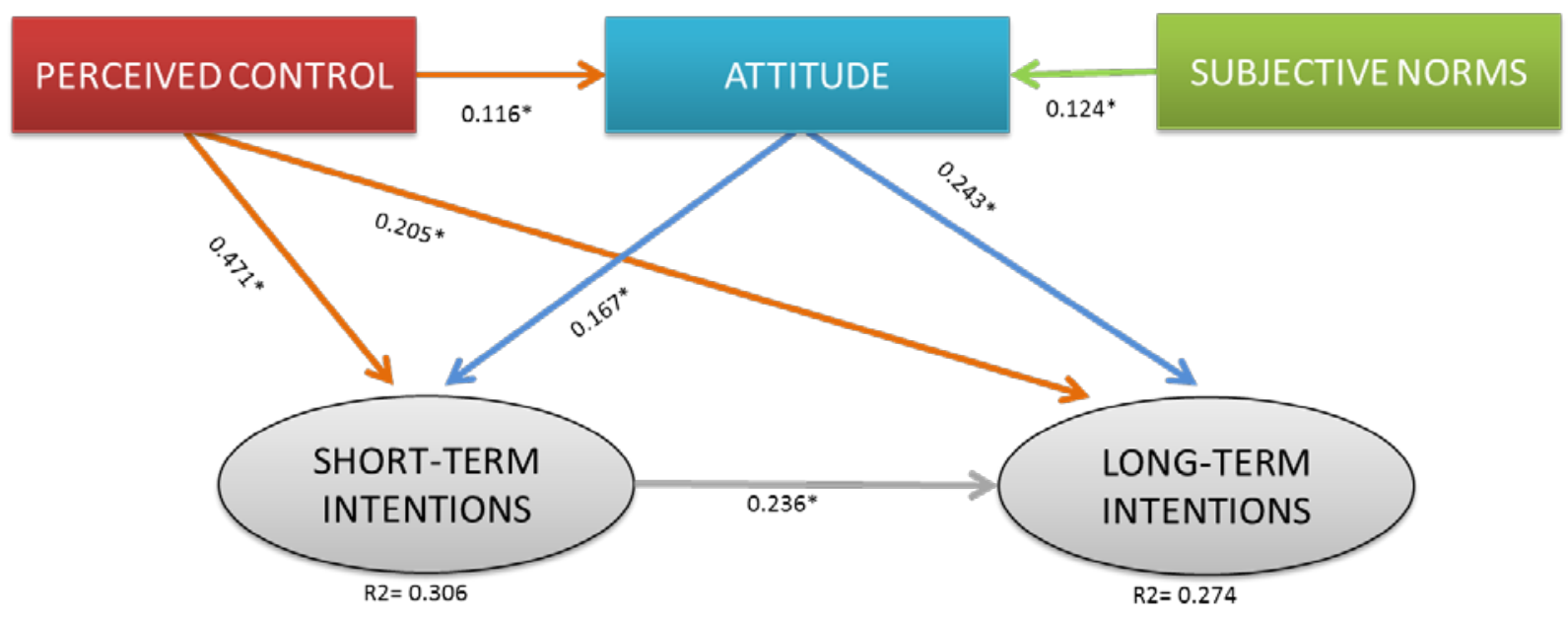

*Path coefficient significant at $1 \%$.

**Path coefficient significant at $5 \%$.

This model again validates $\mathrm{H} 1$ and H2. Similar to G1, subjective norms had no influence on short- and long-term intentions. Perceived control strongly influences intentions in the short term (.471), more so than attitude (.167), and for the first time, its influence (.205) also is equivalent to that of attitude (.243) on entrepreneurial intentions in the long term, though it is affected by both perceived control and subjective norms (H5a and H5b). In this sense, this finding does not confirm the prominent role of attitude in the formation of entrepreneurial intentions (H4). The short- versus longterm intention variable also modifies the influence of the variables (H6).

The members of G3 exhibit a medium level of intentions to start new businesses in the short term but strong intentions in the long term. Their attitudes are very positive toward the act of starting a company. They regard enterprise creation as a very attractive idea and like this career option. They also consider themselves the most capable of starting a business (see Appendix 4). Thus, we refer to the students of group 3 as "future entrepreneurs." Their short-term intentions may be average, but they are still the highest among the three groups studied. This short-term intention is strongly enhanced by perceived control, which is the strongest for this group. Then their declaration of intentions in the long term increase, though paradoxically, they are less well explained by the model, showing a quasi-identical impact that is also moderated by perceived control and attitudes.

This group is composed principally of men, enrolled in management training, from undergraduate to Baccalaureate +5 . They follow a business education program that they find both interesting and useful. Coming from diverse origins, they are surrounded by entrepreneurs, whose initiatives have been mostly successful.

The existence of three submodels validates our prediction of different representations and distinct models to describe the formation of entrepreneurial intentions among the seemingly homogenous group of university students (H7). 
To summarize, the results on hypothesis validation are presented in table 3.

Table 3. Hypothesis validation

\begin{tabular}{cllll}
\hline & \multicolumn{1}{c}{ G1 } & \multicolumn{1}{c}{ G2 } & \multicolumn{1}{c}{ G3 } & \multicolumn{1}{c}{ General model } \\
\hline H1 & Short term: validated & Short term: validated & Short term: validated & Short term: validated \\
& Long term: unvalidated & Long term: validated & Long term: validated & Long term: validated \\
validated
\end{tabular}

\section{Discussion}

Overall, we do not find strong entrepreneurial intentions among this sample of students. However, our results reveal some interesting findings, related to ideas for improving the TPB model, identifying different entrepreneurial intention formation models, and identifying distinct students profiles.

First, we identified two paths for improvement of the TPB model:

- $\quad$ Long- versus short-term distinction. This study highlights the need to distinguish the stages of intention carefully, especially between end-of-study and long-term intentions (H6). Although some longitudinal studies of student populations have appeared (Audet, 2000; Byabashaija and Katono, 2011), they focus on the intention of starting a business, before and after an apprenticeship, rather than on short- versus long-term intentions (Boissin and al., 2009; Audet, 2000). Our results, by revealing the different influences of the variables, according to the temporal horizon, highlight the need for such a distinction. In particular, we argue that the prevalence of attitude (H2) or perceived control (H1) depends on the temporal frame, as well as on the student profile. In all the models, perceived control dominates over attitude in terms of its influence on short-term intentions, at the end of the students' educational careers. But in the long term, it is attitude that takes over (H4).

- Complex role of subjective norms. This study reaffirms the important influence of perceived control and attitude but the weak effect of subjective norms (Ozaralli and Rivenburgh, 2016). In general, subjective norms do not have direct effects but instead exert influences through indirect effects (cf. G1, for whom subjective norms have no influence). When they do come into play, subjective norms affect attitudes (H5a). These results reiterate findings by Krueger et al. (2000), Emin (2004), Liñán and Chen (2009), and Boissin et al. (2009), who conclude that attitude and perceived control are explanatory variables that define entrepreneurial intentions, whereas subjective norms are not significant determinants. Our results also extend these findings, in that we uncover some divergent results that reflect our recognition that the degree of incentive the student perceives for undertaking entrepreneurship, due to his or her social environment (subjective norms), acts indirectly on intention by affecting his or her 
attitude toward an entrepreneurial career. Attitude is thus generally influenced by subjective norms and perceived control in the construction of entrepreneurial intention (H5a and H5b). This finding is in line with Liñán and Chen (2009) and Fretschner and Weber (2013).

Second, the findings enable us to establish student profiles that differ in terms of the processes by which they form entrepreneurial intentions (in support of H7). This latent classification study thus reveals three groups, corresponding to three internal, distinct submodels of entrepreneurial intention, with unique connections among variables that exhibit different intensities: recalcitrants (G1), ambivalents (G2), and future entrepreneurs (G3). The main differences refer to four points:

- The model is more pertinent $\left(\mathrm{R}^{2}\right)$ in terms of explaining intention formation in the short term for group 3. It instead is better at explaining long-term intention formation for groups 1 and 2.

- Perceived control and attitude have different impacts. Perceived control has a vital, direct role in determining short-term intentions in groups 1 and 3. For group 2 though, attitude plays the central role for forming intentions in the long term.

- $\quad$ Subjective norms have a weak but still significant influence in groups 2 and 3, particularly in terms of their indirect effect on attitude.

- The impact of intentions in the short term on intentions in the long term is variable: very important for group 1, but more moderated for groups 2 and 3.

Third, the students who constitute these three groups present socio-demographic characteristics that confirm some prior results. In particular, the socio-demographic characteristics (Appendix 4) that characterize and differentiate these groups pertain to gender, field of study, whether their parents were entrepreneurs at some point, experience, and backgrounds. Many assessments thus can stem from these observations.

For example, in line with prior literature (Boissin et al., 2009; Santos et al., 2016), we find that gender exerts a notable influence on entrepreneurial intentions. Women express weaker intentions than men (short-term intentions, women $=1.73$, men $=1.98$; long-term intentions, women $=3.19$, men = 3.44). In both G1 and G2, in which women are overrepresented, the entrepreneurial intentions expressed are middling or even weak, in contrast with G3, in which men are overrepresented. This result might be explained not only by the level of attraction to business creation, which is weaker among female students, but also by varying perceptions of the capacity to create a business. Female students declare themselves less capable, similar to the findings offered by Shinnar et al. (2014). Similarly, Santos et al. (2016) find that men consistently exhibit more favorable intentions than women do, whereas women perceive the entrepreneurial role as less adequate for them, compared with men.

Furthermore, the course of study that students have chosen exercises a strong influence on which model of entrepreneurial intention they follow. In G3, with the strongest entrepreneurial intentions, a management course of study is most common. We propose a dual explanation for this finding: This course of study might establish an apprentice-like environment, introducing students to the world of enterprise and start-up organizations in general, that acts on their intentions, or this course of study might attract students who already are aware of and interested in entrepreneurship. Further studies should try to pinpoint the manner and the degree to which the course of study affects the antecedents of intention.

Fourth and finally, the distinction of the three models of the formation of entrepreneurial intention, and their specification of the unique determinants for various groups, enables us to recommend pertinent pedagogical action strategies. For example, the future entrepreneurs in G3 are marked by strong entrepreneurial intentions in the short and long term. These students, mostly coming from management training, are at a relative advantage in terms of understanding models of entrepreneurship, so they likely develop better perceived control, which in turn exerts a strong impact 
on the formation of their intentions. Considering the benefits of strategic placements of pertinent modules, business schools and universities should design their entrepreneurship programs according to students' acquisition of competencies. For students with strong intentions, the schools should accentuate entrepreneurial behavior. A national or international student-entrepreneur framework might help define the clear path for transitioning into entrepreneurial behavior. Acting on this attraction is less important in the short term though, because these students already have a positive image of entrepreneurship, due to their backgrounds.

However, the recalcitrant in G1 have very weak entrepreneurial intentions, principally due to their weak perceived control. Thus the entrepreneurship modules for these students should focus on enhancing their competencies (e.g., business planning, strategy formulation, market analysis, financing), which they seem to lack. Even better, the curriculum might aim to provide them with longer courses devoted to management topics.

Finally, the ambivalents in G2 need to have their long-term intentions reinforced. For these students, the creation of an enterprise is not part of their short-term, professional projects (e.g., the overrepresented engineers are focused on other projects). The model also does not suggest options for leveraging the effects on short-term intentions. However, their more favorable attitude with regard to business creation strongly affects their long-term intention. Therefore, continuing to reinforce these positive attitudes represents a meaningful priority for schools.

For Groups 1 and 2, the overrepresentation of women also requires some consideration. Education programs might emphasize models of female entrepreneurs or invite successful female entrepreneurs to provide guest lectures, which could encourage stronger entrepreneurial intentions among female students.

As the result of an initial investigation of entrepreneurial intentions, this typology provides milestones for reflecting on the content of entrepreneurial education, in terms of both awareness formation and support for enterprise creation.

\section{CONCLUSIONS, IMPLICATIONS, AND LIMITATIONS}

This original study investigates an important population of students, using a data set of more than 2,267 responses. This substantial sample compares favorably with other studies of the entrepreneurial intentions of students.

We pursued three research objectives with this study, seeking to enhance the TPB to reflect the specificities of diverse student populations and describe how the weight of the determinants varies in terms of affecting the entrepreneurial intentions of these differing student profiles. Accordingly, our results provide a more fine-grained understanding of the model of entrepreneurial intentions, based in the TPB. We demonstrate that the influence of the variables also changes and evolves, according to the temporal horizon. By extracting and characterizing three student profiles, we specify that the determinants of intention are not identical, nor do they have the same influences across groups of students.

Our third objective was to characterize students' profiles according to socio-demographic variables, which then could inform the development of more targeted, better suited educational programs. Our results thus offer recommendations for educators who want to encourage positive attitudes or capabilities among students who might pursue entrepreneurship. This article provides a foundation for constructing business education programs that are better adapted to the various kinds of student populations (e.g., encouraging attitude vs. support for business formation).

The generalizability of these results is not guaranteed though. Several limitations establish boundaries on the results. In particular, this study was carried out in one region in France (MidiPyrenees), and students from this region may not be fully representative of the general population. 
Because student samples in different regions or countries might yield conflicting results, further research is necessary to confirm or refute these results in various settings.

Furthermore, our work is limited by an inherent trait of models of intention: The measure of entrepreneurial intentions offers simply a snapshot, at a single instant and in a particular context (Ajzen and Fishbein, 1980; Bratman, 1987). Declaring an intention is no guarantee that the predicted action or behavior will follow. However, this study features a population (i.e., students) whose primary purpose and focus is constructing intentions for the future and choosing their professional paths. Furthermore, our measure of intentions, spanning the short and long terms, allows us to compensate somewhat for this limitation. Observations over time could help address this issue and reveal the presence of any discrepancies between short-term intentions and entrepreneurial behavior.

In addition, this study concentrates on an internal model of entrepreneurial intention, with only partial consideration of the influences of external factors. Moreover, we adopted a somewhat reductionist view of enterprise, such that our questionnaire items focused only on the creation of an enterprise. Although the introduction to the questionnaire emphasized a broad view of enterprise (i.e., freelance, worldwide, business creation), to simplify the survey, the questions often cited the context of enterprise creation.

We used TPB as a foundation to predict the need to distinguish different entrepreneurial intention formation processes, based on students' cognitive and demographic profiles. The results show that entrepreneurship education curricula should be designed and targeted according to these profiles. Further research also might use an integrated model (TPB-EEM; Schlaegel and Koenig, 2014) to achieve a more complete view of the phenomenon. In France, the student-entrepreneur status also offers the possibility of identifying students engaged in entrepreneurial behavior for continued research. With such a sample, it may be easier to measure people's propensity to act on entrepreneurial opportunities (Krueger et al., 2000).

In terms of its managerial implications, this study suggests the critical need, particularly in educational settings, to create teaching models that reflect the differentiated student profiles (Fayolle and Gailly, 2009; Fretschner and Weber, 2013). To encourage students to develop some attraction to entrepreneurship, it may be more pertinent to provide tools for developing their attitudes, not increasing their competencies. If some students already intend to create an enterprise though, it makes sense to enhance their entrepreneurial capabilities. The various student profiles require very different forms of support and defined objectives from their education programs. Additional research should extend our work to specify the influence of the different programs, in terms of how they reinforce students' attitudes and perceived control.

Along these lines, certain lessons might create some attraction to entrepreneurship among students who perceive themselves as distant from the very idea of business creation. Other lessons could act more on the competencies of students already convinced of this career path and who want to make the transition to entrepreneurial behavior in the short term, such as with a studententrepreneur status. In clarifying the process by which entrepreneurial intentions are formed, this research provides insights for universities and other higher education institutions to develop adapted education programs and enhance the effectiveness of the lessons they provide. It is important to develop further models too, not just for apprenticeship initiatives but also for awareness efforts (e.g., practice in real social enterprise projects) and entrepreneurial behaviors (e.g., support for studententrepreneurs by allowing action formation). These new forms of awareness and support can provide good interventions to enhance both the attraction to and the capacity to start up a new business. These student-entrepreneurs offer an interesting population that may help bridge the entrepreneurial intention-behaviour gap, with studies of the role of commitment and implementation intention among this unique group of students (Adam and Fayolle, 2015). 


\section{REFERENCES}

Adam, A. F., \& Fayolle, A. (2015). Bridging the entrepreneurial intention-behaviour gap: the role of commitment and implementation intention. International Journal of Entrepreneurship and Small Business, 25(1), 36-54.

Ajzen, I. (1987). Attitudes, traits, and actions: Dispositional prediction of behavior in personality and social psychology. Advances in experimental social psychology, 20(1), 1-63.

Ajzen, I. (1991). The theory of planned behavior. Organizational behavior and human decision processes, 50(2):179-211.

Ajzen, I., and Fishbein, M. (1980). Understanding attitudes and predicting social behavior, PrenticeHall, 278 p.

Armitage, C. J., and Conner, M. (2001). Efficacy of the theory of planned behaviour: A meta-analytic review. British journal of social psychology, 40(4):471-499.

Audet, J. (2000). Evaluation of two approaches to entrepreneurship education using an intentionbased model of venture creation. Academy of Entrepreneurship Journal, 6(1):58-63.

Bae, T.J., Qian S., Miao C., Fiet J.O. (2014). The relationship between entrepreneurship education and entrepreneurial intentions: a meta-analytic review. Entrepreneurship Theory and Practice. 38(2):217-254.

Bandura, A. (1997). Self-efficacy: The exercise of control. New York: Freeman

Boissin, J. P., Branchet, B., Emin, S. and Herbert, J. I. (2009). Students and entrepreneurship: a comparative study of France and the United States. Journal of Small Business \& Entrepreneurship, 22(2):101-122.

Bratman M. (1987). Intention, Plans, and Practical Reason, Cambridge, MA: Harvard University Press.

Bruyat, C. (2001). Créer ou ne pas créer?. Revue de l'Entrepreneuriat, 1(1), 25-42.

Byabashaija W. and Katono I. (2011). The impact of college entrepreneurial education on entrepreneurial attitudes and intention to start a business in Uganda, Journal of Developmental Entrepeneurship, 16 (2):27-144.

Carrier, C. (2000). Défis, enjeux et pistes d’action pour une formation entrepreneuriale renouvelée. Gestion 2000, mai-juin, 149-163.

Chabaud, D., \& Messeghem, K. (2010). Le paradigme de l'opportunité. Revue française de gestion, (7), 93-112.

Chin, W.W. and Dibbern, J. (2010). An introduction to a permutation based procedure for multigroup PLS analysis: Results of tests of differences on simulated data and a cross cultural analysis of the sourcing of information system services between Germany and the USA. Handbook of partail least squares, 171-193.

Emin, S. (2004). Les facteurs déterminant la création d'entreprise par les chercheurs publics: application des modèles d'intention. Revue de l'Entrepreneuriat, 3(1), 1-20.

Esposito Vinzi, V., Squillacciotti, S. and Tenenhaus, M. (2008). REBUS-PLS: A response-based procedure for detecting unit segments in PLS path modelling. Applied Stochastic Models In Business and Industry, 24:439-458. 
Fayolle, A. (2001). D'une approche typologique de l'entrepreneuriat chez les ingénieurs à la reconstruction d'itinéraires d'ingénieurs entrepreneurs. Revue de l'entrepreneuriat, 1(1), 77-97.

Fayolle, A. and Gailly, B. (2009). Évaluation d'une formation en entrepreneuriat: prédispositions et impact sur l'intention d'entreprendre.M@n@gement, 12(3), 176-203.

Farooq, O., Merunka, D. and Valette-Florence, P. (2013). Employees’ Response to Corporate Social Responsibility : An Application of A Non Linear Mixture REBUS Approach. In New Perspectives in Partial Least Squares and Related Methods. Springer New York: 257-268.

Fitzsimmons, J. R. and Douglas, E. J. (2011). Interaction between feasibility and desirability in the formation of entrepreneurial intentions. Journal of Business Venturing, 26(4):431-440.

Fretschner, M. and Weber, S. (2013). Measuring and understanding the effects of entrepreneurial awareness education. Journal of Small Business Management, 51(3): 410-428.

Henseler, J., Ringle, C.M. and Sinkovics, R.R. ( 2009). The use of partial least squares path modelling in international marketing. Advances in International Marketing, 20:277-319.

Kolvereid, L. (1996). Prediction of employment status choice intentions. Entrepreneurship Theory and Practice, 21(1), 47-58.

Kolvereid, L. and Isaksen, E. J. (2012). The Psychology of the Entrepreneur'. Perspectives in Entrepreneurship: A Critical Approach, 27-39.

Krueger N.F (1993). Impact of prior entrepreneurial exposure on perceptions of new venture feasibility and desirability. Entrepreneurship Theory and Practice. 18(1):5-21

Krueger N.F (2000). The cognitive infrastructure of opportunity emergence, Entrepreneurship Theory and Practice. 24(3):9-27.

Krueger, N.F., Reilly, M.D. and Carsrud, A.L. (2000). Competing models of entrepreneurial intentions. Journal of Business Venturing, 15(5-6):411-432.

Liñán, F. and Chen, Y.W. (2009). Development and cross-cultural application of a specific instrument to measure entrepreneurial intentions. Entrepreneurship Theory and Practice, 33(3): 593-617.

Liñán, F. and Fayolle, A. (2015). A systematic literature review on entrepreneurial intentions: citation, thematic analyses, and research agenda. International Entrepreneurship and Management Journal, 11(4), 907-933.

Lüthje, C. and Franke, N. (2003). The 'making' of an entrepreneur: testing a model of entrepreneurial intent among engineering students at MIT. R\&D Management, 33(2):135-147.

Moreau, R. \& Raveleau (2006). Les trajectoires de l'intention entrepreneuriale. Revue internationale PME, 19 (2), 101-131.

Ozaralli, N. and Rivenburgh, NK (2016). Entrepreneurial intention: Antecedents to entrepreneurial behavior in the U.S.A. and Turkey. Journal of Global Entrepreneurship Research, 6(3):1-32.

Plant R. and Ren J. (2010). A comparative study of motivation and entrepreneurial intentionality: Chinese and American perspectives. Journal of Developmental Entrepreneurship, 15(2):187-204

Rueda, S., Moriano, J. A. and Liñán, F. (2015). Validating a theory of planned behavior questionnaire to measure entrepreneurial intentions. In Fayolle, Kiro et Linan, Developing, Shaping and Growing Entrepreneurship, 60. 
Santos, F.J., Roomi, M.A. and Liñán, F. (2016). About gender differences and the social environment in the development of entrepreneurial intentions. Journal of Small Business Management, 54(1):4966.

Shapero, A. and Sokol, L. (1982). The social dimensions of entrepreneurship, Encyclopedia of entrepreneurship, 72-90.

Schlaegel, C. and Koenig M. (2014). Determinants of entrepreneurial intent: A meta-analytic test and integration of competing models, Entrepreneurship Theory and Practice, 38(2):291- 332.

Shinnar, R. S., Hsu, D. K. and Powell, B. C. (2014). Self-efficacy, entrepreneurial intentions, and gender: Assessing the impact of entrepreneurship education longitudinally, The International Journal of Management Education, 12(3):561-570.

Shook, C. L., Priem, R. L. and McGee, J. E. (2003). Venture creation and the enterprising individual: a review and synthesis, Journal of Management, 29 (3):379-399

Tkachev, A. and Kolvereid, L. (1999). Self-employment intentions among Russian students, Entrepreneurship \& Regional Development, 11(3):269-280. 


\section{Appendix 1: Theory of planned behavior}

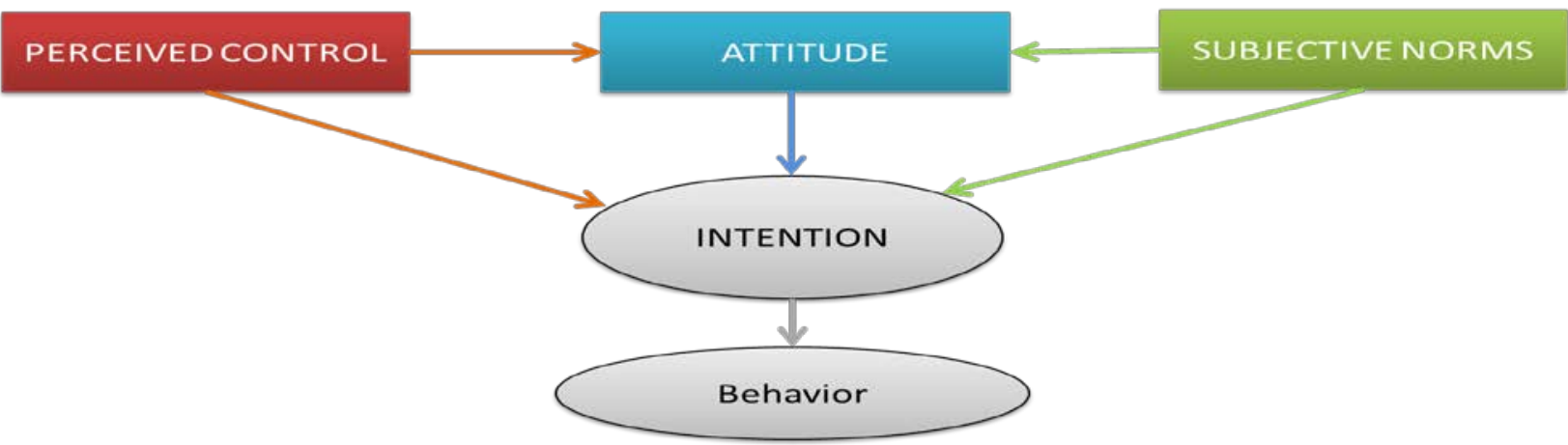

Source: Adapted from Ajzen (1987, 1991) 
Appendix 2: Allotment of the sample by establishment

\begin{tabular}{|c|c|c|}
\hline Establishments & Frequency & $\%$ \\
\hline Architecture & 38 & 1,7 \\
\hline University CUFR & 75 & 3,3 \\
\hline Doctoral School & 254 & 11,2 \\
\hline Engineering school & & 57 \\
\hline EIPurpan & $1<J$ & , \\
\hline Engineering School & & \\
\hline EMAC & $4 I$ & $2, \perp$ \\
\hline Engineering School & 20 & 17 \\
\hline ENAC & 39 & $\perp, I$ \\
\hline Engineering School & 21 & 0 \\
\hline ENIT & $\angle \perp$ & , \\
\hline Law ENM & 139 & 6,1 \\
\hline Engineering School & ? & \\
\hline ENSEEIHT & 30 & 2,3 \\
\hline Engineering School & 55 & ? \\
\hline ENSIACET & 50 & \\
\hline Toulouse Business & 252 & 150 \\
\hline School GESCT & & 15,6 \\
\hline Engineering School & & 5 \\
\hline ICAM & 12 & J \\
\hline SHS IEP & 101 & 4,5 \\
\hline Engineering School & & 1 \\
\hline INPT & 3 &,+ \\
\hline Engineering School & م2 & 7 \\
\hline INSAT & $2<0$ & 9,1 \\
\hline Engineering School & 72 & 22 \\
\hline ISAE & 10 & 3,2 \\
\hline University Toulouse1 & 66 & 2,9 \\
\hline University Toulouse2 & 203 & 9,0 \\
\hline University Toulouse3 & 371 & 16,4 \\
\hline Others & 15 & ,7 \\
\hline Total & 2267 & 100,0 \\
\hline
\end{tabular}

Source: http://www.univ-toulouse.fr/universite/presentation/etablissements-membres 


\section{Appendix 3: Measurement quality}

\begin{tabular}{|c|c|c|c|c|}
\hline Concepts & Latent variables & First-order factor and manifest variables & $\begin{array}{l}\text { Rho } \\
\text { of DG }\end{array}$ & $\begin{array}{l}\text { Converge } \\
\text { nt } \\
\text { validity } \\
\text { (\% of } \\
\text { shared } \\
\text { variance) }\end{array}$ \\
\hline \multirow{6}{*}{$\begin{array}{c}\text { Beliefs / } \\
\text { Capacities for } \\
\text { Entrepreneurs } \\
\text { hip } \\
\text { “To what } \\
\text { degree do you } \\
\text { feel capable, } \\
\text { today, of } \\
\text { accomplishing } \\
\text { the tasks } \\
\text { necessary for } \\
\text { the creation of } \\
\text { an enterprise?” }\end{array}$} & \multirow{6}{*}{$\begin{array}{l}\text { Second-order } \\
\text { factor } 1 \text { : } \\
\text { Beliefs/capacities }\end{array}$} & F1- BP Fundamentals & \multirow[t]{2}{*}{0.878} & \multirow[t]{2}{*}{0.593} \\
\hline & & $\begin{array}{l}\text { Finding an idea of product or service } \\
\text { Assessing the risk of the project } \\
\text { Finding relevant information regarding the market and } \\
\text { potential customers } \\
\text { Finding relevant information regarding competitors } \\
\text { Evaluating the financial needs of the project }\end{array}$ & & \\
\hline & & F2- Financial attractiveness & \multirow[t]{2}{*}{0.845} & \multirow[t]{2}{*}{0.642} \\
\hline & & $\begin{array}{l}\text { Raising funds through banks } \\
\text { Attracting love money } \\
\text { Attracting investors / potential shareholders }\end{array}$ & & \\
\hline & & F3- Human competencies & \multirow[t]{2}{*}{0.858} & \multirow[t]{2}{*}{0.501} \\
\hline & & $\begin{array}{l}\text { Finding the right people to work with you } \\
\text { Handling administrative tasks required to launch the business } \\
\text { Devoting all time and energy to the project } \\
\text { Finding the people or institutions able to help and advise you } \\
\text { Planning the creation process } \\
\text { Managing people }\end{array}$ & & \\
\hline \multirow{8}{*}{$\begin{array}{l}\text { Beliefs/Attracti } \\
\text { on to } \\
\text { Entrepreneurs } \\
\text { hip }\end{array}$} & \multirow{6}{*}{$\begin{array}{l}\text { Second-order } \\
\text { Factor } 1 \text { : } \\
\text { Independence }\end{array}$} & F1-Autonomy/independence & \multirow[t]{2}{*}{0.852} & \multirow[t]{2}{*}{0.593} \\
\hline & & $\begin{array}{l}\text { To work autonomously } \\
\text { To be your own boss } \\
\text { To have responsibility } \\
\text { To have power }\end{array}$ & & \\
\hline & & F2- Development & \multirow[t]{2}{*}{0.840} & \multirow[t]{2}{*}{0.512} \\
\hline & & $\begin{array}{l}\text { To have an interesting job } \\
\text { To realize your dreams } \\
\text { To express your creativity } \\
\text { To follow work tasks from A to Z } \\
\text { To do something useful for the community }\end{array}$ & & \\
\hline & & F6- Taste for challenge & \multirow[t]{2}{*}{0.769} & \multirow[t]{2}{*}{0.601} \\
\hline & & $\begin{array}{l}\text { To take risks } \\
\text { To face challenges }\end{array}$ & & \\
\hline & & F3- Tranquility & \multirow[t]{2}{*}{0.864} & \multirow[t]{2}{*}{0.613} \\
\hline & & To not have too much work & & \\
\hline
\end{tabular}




\begin{tabular}{|c|c|c|c|c|}
\hline & \multirow{3}{*}{$\begin{array}{l}\text { Second-order } \\
\text { Factor } 2 \text { : } \\
\text { Security }\end{array}$} & $\begin{array}{l}\text { To not have a stressful job } \\
\text { To have free time for leisure, for you family and friends } \\
\text { To have a simple, uncomplicated job }\end{array}$ & & \\
\hline & & F5-Security & \multirow[t]{2}{*}{0.903} & \multirow[t]{2}{*}{0.822} \\
\hline & & $\begin{array}{l}\text { To have a job security } \\
\text { To have a stable income }\end{array}$ & & \\
\hline & \multirow[b]{2}{*}{$\begin{array}{l}\text { First-order Factor : } \\
\text { Recognition }\end{array}$} & F4-Recognition & \multirow[t]{2}{*}{0.822} & \\
\hline & & $\begin{array}{l}\text { To achieve a recognized social status } \\
\text { To get compensation based on your commitment } \\
\text { To achieve high levels of income or earnings } \\
\text { To have opportunities for carrier progress }\end{array}$ & & \\
\hline \multirow[b]{6}{*}{$\begin{array}{c}\text { Beliefs/Professi } \\
\text { onal Life }\end{array}$} & \multirow{4}{*}{$\begin{array}{l}\text { Second-order } \\
\text { Factor } 1 \text { : Security }\end{array}$} & F1- Tranquility & \multirow[t]{2}{*}{0.850} & \multirow[t]{2}{*}{0.534} \\
\hline & & $\begin{array}{l}\text { To note have too much work } \\
\text { To not have a stressful job } \\
\text { To have free time for leisure, for you family and friends } \\
\text { To have a simple, uncomplicated job } \\
\text { To have a job with low levels of responsibility }\end{array}$ & & \\
\hline & & F5 Security & 0.904 & 0.563 \\
\hline & & $\begin{array}{l}\text { To have job security } \\
\text { To have a stable income }\end{array}$ & & \\
\hline & \multirow{6}{*}{$\begin{array}{l}\text { Second-order } \\
\text { Factor } 2 \text { : } \\
\text { Independence }\end{array}$} & F2- Recognition/money & \multirow[t]{2}{*}{0.818} & \multirow[t]{2}{*}{0.528} \\
\hline & & $\begin{array}{l}\text { To achieve a recognized social status } \\
\text { To get compensation based on your commitment } \\
\text { To achieve high levels of income or earnings } \\
\text { To have opportunities for carrier progress }\end{array}$ & & \\
\hline \multirow{6}{*}{$\begin{array}{l}\text { “For each of } \\
\text { the following } \\
\text { elements, } \\
\text { identify the } \\
\text { importance you } \\
\text { give it for the } \\
\text { quality of your } \\
\text { professional } \\
\text { life..." }\end{array}$} & & F3- development & \multirow[t]{2}{*}{0.807} & \multirow[t]{2}{*}{0.824} \\
\hline & & $\begin{array}{l}\text { To take risks } \\
\text { To face challenges } \\
\text { To realize your dreams } \\
\text { To express your creativity } \\
\text { To follow work tasks from A to Z } \\
\text { To do something useful for the community }\end{array}$ & & \\
\hline & & F4-Independence & \multirow[t]{2}{*}{0.837} & \multirow[t]{2}{*}{0.413} \\
\hline & & $\begin{array}{l}\text { To work autonomously } \\
\text { To be your own boss } \\
\text { To have responsibility } \\
\text { To have power }\end{array}$ & & \\
\hline & \multirow{2}{*}{$\begin{array}{l}\text { First-order Factor: } \\
\text { Interest in the work }\end{array}$} & F6-Interest in the work & \multirow{2}{*}{\multicolumn{2}{|c|}{ not calculated }} \\
\hline & & To have an interesting job & & \\
\hline \multicolumn{2}{|l|}{ Perceived control } & F1: Perceived control & 0.828 & 0.705 \\
\hline
\end{tabular}




\begin{tabular}{|c|c|c|c|}
\hline $\begin{array}{l}\text { "Do you consider yourself to be } \\
\text {...?” }\end{array}$ & $\begin{array}{l}\text { Capable of initiating a business in the long term } \\
\text { Capable of creating a business at the end of yours studies }\end{array}$ & & \\
\hline \multirow[t]{2}{*}{ Attitude/Entrepreneurship } & F1 : Attitude & \multirow[t]{2}{*}{0.874} & \multirow[t]{2}{*}{0.775} \\
\hline & $\begin{array}{l}\text { The idea of creating your business seems attractive to you } \\
\text { Absolutely, you would like to create a business }\end{array}$ & & \\
\hline \multirow[t]{2}{*}{ Subjective Norm } & F1 : subjective norm & \multirow[t]{2}{*}{0.864} & \multirow[t]{2}{*}{0.602} \\
\hline & $\begin{array}{l}\text { Family opinion/business creation * weight of this opinion } \\
\text { Friends opinion/business creation * weight of this opinion } \\
\text { Teachers opinion/business creation * weight of this opinion } \\
\text { People who are important for you opinion/business creation * } \\
\text { weight of this opinion }\end{array}$ & & \\
\hline \multirow[t]{2}{*}{ End-of-Study Intention } & F1 :End-of-study Intention & \multirow{2}{*}{$\begin{array}{l}\text { not } \\
\text { calcula } \\
\text { ted }\end{array}$} & \multirow[t]{2}{*}{0.584} \\
\hline & $\begin{array}{l}\text { Probability to create a business at the end of your studies } \\
\text { Probability to be employed by someone at the end of your } \\
\text { studies }\end{array}$ & & \\
\hline \multirow[t]{2}{*}{ Intention at Term } & F1: Intention at term & \multirow{2}{*}{\multicolumn{2}{|c|}{ not calculated }} \\
\hline & Probability to create a business in your professional career & & \\
\hline
\end{tabular}




\section{Appendix 4: Characterization of the three groups}

A4.1 Overrepresentations of socio demographic variables in the three groups

\begin{tabular}{|c|c|c|c|}
\hline Socio-demographics & $\begin{array}{c}\text { Group } 1 \\
\text { Recalcitrants } \\
\text { (Theoretical \%: 9.1\%) }\end{array}$ & $\begin{array}{c}\text { Group } 2 \\
\text { Ambivalents } \\
\text { (Theoretical \%: } 58.5 \% \text { ) }\end{array}$ & $\begin{array}{l}\text { Group } 3 \\
\text { Future entrepreneurs } \\
\text { (Theoretical \%: } 32.3 \% \text { ) }\end{array}$ \\
\hline Gender** & Women (9.8\%) & Women (62.5\%) & Men (37.2\%) \\
\hline Country of origin** & $\begin{array}{l}\text { West Europe }(16.7 \%) \\
\text { South America }(12.5 \%) \\
\text { East Europe }(11.8 \%) \\
\text { Oceania }(11.1 \%)\end{array}$ & France (60.6\% vs 58.4\%) & $\begin{array}{l}\text { North America (100\%) } \\
\text { East Europe (47.1\%) } \\
\text { West Europe (39.6\%) } \\
\text { Oceania (55.6\%) } \\
\text { South America (56.3\%) } \\
\text { Asia (56\%) }\end{array}$ \\
\hline Study domains** & $\begin{array}{l}\text { Law/Eco/SHS (1) (12.5\%) } \\
\text { Arts/Letters (14.8\%) } \\
\text { SVT (2) }(11.4 \%)\end{array}$ & $\begin{array}{l}\text { Law/Eco/SHS }(63 \%) \\
\text { Science/Engineering/Technology } \\
(61.2 \%)\end{array}$ & $\begin{array}{l}\text { Management (36.3\%) } \\
\text { Arts/Letters (33.6\%) } \\
\text { SVT (33.7\%) }\end{array}$ \\
\hline Levels of study** & $\begin{array}{l}\text { Bac }+1(12.8 \%) \\
\text { Doctorate }(12.4 \%)\end{array}$ & $\mathrm{Bac}+5(69.2 \%)$ & All levels except Bac + 5 \\
\hline Parents creators** & Balance & No parent creators $(62 \%)$ & Parent creators (40\%) \\
\hline Relatives creators** & Balance & No relative creators (63.5\%) & Relative creators (36.2\%) \\
\hline Creation success** & Mostly failures (13.2\%) & Mostly failures (64.6\%) & Mostly successes (37.8\%) \\
\hline
\end{tabular}

$*$ Significant at $1 \%$

**Significant at $5 \%$

(1): SHS refers to humanities and social science majors.

(2): SVT implies science-oriented studies.

Notes: $\mathrm{Chi}^{2}$ tests applied between each descriptive variable and the three groups identified by the typology. The modalities that appear below each group characterize and differentiate the groups. 


\section{A4.2 Characterization of the three groups from the main model variables}

Overrepresentations of main model variables in the three groups

\begin{tabular}{|l|}
\hline Intention creation \\
\hline Short Term * \\
\hline Long Term* \\
\hline Attitude* \\
\hline Perceived Control * \\
\hline
\end{tabular}

\begin{tabular}{|l|}
\multicolumn{1}{|c|}{$\begin{array}{c}\text { Group 1 } \\
\text { Recalcitrants }\end{array}$} \\
\hline Weak \\
Middling \\
Weak \\
Weak
\end{tabular}

\section{nts}

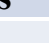

\begin{tabular}{|l|l|}
\hline \multicolumn{1}{|c|}{$\begin{array}{c}\text { Group } 2 \\
\text { Ambivalents }\end{array}$} \\
\hline Very weak \\
\hline Middling \\
\hline Middling \\
\hline Weak \\
\hline
\end{tabular}

Descriptive analysis for the main model variables

\begin{tabular}{|c|c|c|c|c|}
\hline & $\begin{array}{c}\text { Group } 1 \\
\text { Recalcitrants }\end{array}$ & $\begin{array}{c}\text { Group } 2 \\
\text { Ambivalents }\end{array}$ & $\begin{array}{c}\text { Group } 3 \\
\text { Future } \\
\text { entrepreneurs }\end{array}$ & Median \\
\hline \multicolumn{5}{|l|}{ Entrepreneurial Intention } \\
\hline Probability of creating a business at the end of study?** & 1.91 & 1.31 & 2.81 & 1.86 \\
\hline Probability of someday creating a business in prof. life?** & 2.85 & 2.93 & 4.14 & 3.32 \\
\hline \multicolumn{5}{|l|}{ Attitude } \\
\hline Idea of creating is attractive** & 3.09 & 3.58 & 4.73 & 3.91 \\
\hline Like to create his/her business** & 2.41 & 3.02 & 4.36 & 3.4 \\
\hline \multicolumn{5}{|l|}{ Perceived Control } \\
\hline Capable at end of studies of creating his/her own business** & 2.17 & 1.99 & 2.95 & 2.32 \\
\hline Capable in time of creating his/her own business** & 3.18 & 3.44 & 4.19 & 3.66 \\
\hline \multicolumn{5}{|l|}{ Subjective Norms } \\
\hline Your family’s opinion** & 3.64 & 3.67 & 4.06 & 4 \\
\hline Your friends' opinions** & 3.78 & 3.92 & 4.21 & 3.46 \\
\hline His/her professors’ opinions** & 3.57 & 3.68 & 3.86 & 3.45 \\
\hline Important people’s opinions** & 3.73 & 3.82 & 4.22 & 4.04 \\
\hline
\end{tabular}

*Significant F-Tests: 1\%

**Significant F-Tests: 5\% 